\title{
Sulfur isotope ratios of the Akatani, Iide and Waga-Sennin skarn deposits, and their bearing on mineralizations in the "Green Tuff" region, Japan
}

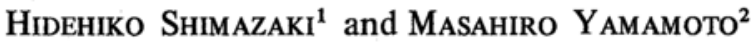 \\ Geological Institute, Faculty of Science, University of Tokyo, Tokyo $113,{ }^{1}$ and \\ Department of Earth Sciences, Faculty of Science, Okayama University, Okayama $700,{ }^{2}$ Japan
}

(Received September 30, 1982: Accepted June,9, 1983)

\begin{abstract}
Sulfur isotope ratios of sulfide minerals from the Akatani, lide and Waga-Sennin skarn deposits formed in the "Green Tuff" region, fall in a rather broad range from +2.8 to $+8.9 \%$. Estimated formation conditions of ores, that is, high oxygen fugacities and relatively low temperatures and $\mathrm{pH}$, certify the predominance of sulfate sulfur over sulfide sulfur in the ore-forming solutions. Irreversible, fast precipitation of sulfide minerals from such sulfate-dominant solutions is thought to have resulted in insignificant isotopic fractionation between aqueous sulfate and sulfide minerals. The obtained range of isotopic values is almost identical with those for sulfide minerals from other type, vein and kuroko, deposits in the "Green Tuff" region. This regularity of sulfur isotope values for many different type deposits in the region suggests the possibility that ore sulfur was supplied from a common provenance, such as Miocene felsic igneous rocks, without any significant isotopic fractionations in the transportation and precipitation processes.
\end{abstract}

\section{INTRODUCTION}

The sulfur isotope study is indispensable for understanding the origin of sulfur and physicochemical features prevailing in the ore-forming process. Since a pioneer work by TATSUMI (1965), however, the accumulation of data seems to have been slow, especially on the sulfur isotopic features of individual hydrothermal vein and skarn deposits in Japan. The only available data to date include TAtsumi (1965) on the Osarizawa and Ani $\mathrm{Cu}$ vein deposits, Yakumo $\mathrm{Mn}-\mathrm{Zn}-\mathrm{Pb}$ vein deposits, Taishu $\mathrm{Zn}-\mathrm{Pb}$ vein deposits and Chichibu $\mathrm{Cu}-\mathrm{Zn}-\mathrm{Pb}-\mathrm{Fe}$ skarn deposits, KrYosu and NAKAI (1971) on the Kamioka Zn-Pb skarn deposits, KIYosu (1974) on the Toyoha $\mathrm{Zn}-\mathrm{Pb}$ vein deposits, Yамамото (1974a) on the Akenobe Cu-Zn-Pb-Sn-W vein deposits, Yамамото (1976) on the Mihara $\mathrm{Cu}$ Fe skarn deposits, KrYosu (1977) on the Taishu $\mathrm{Zn}-\mathrm{Pb}$ vein deposits, ShimaZaKI and Yamamoto (1979) on the Yoshioka Cu skarn deposits, Tsumo Cu-Zn-Pb-W skarn deposits, Kawayama Cu-Zn skarn deposits, Kuga, Fujigatani, Kiwada and Kagata W(-Cu) skarn deposits and Hoei Zn-
Cu-Sn skarn deposits, and IsHIHARA et al. (1981) on the Akenobe vein deposits.

In order to collect information as much as possible on the ore-forming process of hydrothermal deposits, the present writers have planned to determine sulfur isotope ratios of representative deposits in Japan (SHIMAZAKI and Yamamoto, 1979). The result given in the present paper is a part of those obtained through this project. In the previous paper (SHIMAZAKI and Yамамото, 1979), studied deposits were selected because some features in the deposits suggest relatively reducing environments established at the time of mineral deposition. The reducing environments certify the predominance of reduced sulfur species in the ore-forming solutions, and mostly negative $\delta^{34} \mathrm{~S}$ values $(+0.7$ to $-12.2 \%$ ) obtained for sulfides are thought to be close to those for total sulfur in the solutions responsible for the deposits.

In the present work, the deposits formed in oxidizing environments are selected in order to check the effect of oxidation states of ore-forming solutions on the fractionation of sulfur isotopes. The Akatani $\mathrm{Fe}-\mathrm{Cu}$, Iide $\mathrm{Zn}-\mathrm{Pb}-\mathrm{Cu}-\mathrm{Fe}$, 
and Waga-Sennin $\mathrm{Fe}-\mathrm{Cu}$ skarn deposits are characterized by the precipitation of large amounts of hematite, and are peculiar among many skarn deposits in Japan. The locality of the deposits studied in this paper is given in Fig. 1. All the deposits are distributed in the Miocene submarine volcanic region known as the "Green Tuff" region.

\section{OUtLINE OF ORE DEPOSITS}

The Akatani $\mathrm{Fe}-\mathrm{Cu}$ mine The mine is located about $40 \mathrm{~km}$ east-southeast of Niigata City, Niigata Prefecture. Many papers were published on the deposits of this area (e.g. ImaI, 1952, 1960; MoRITA, 1960; Japan Mining Industry Association, 1965; IMAI and YAMAZAKI, 1967; SuZUKI, 1970). According to these papers, the area consists of late Paleozoic shale, sandstone, chert, limestone and basic tuff, intruded by late Cretaceous granodiorite to leucogranite. In and on this basament rocks, various kinds of intrusive and extrusive rocks occurred in Neogene time. Among them, plagioclase rhyolite of middle Miocene age is widely distributed in the mining area, and is called "Akatani rhyolite". The rock generally occurs as extrusives at the surface covering the basement rocks, while the presence of dikes of the rock is also confirmed at depth.

There are three large deposits in the mine, named Bawarizawa, Sudachizawa and Mizunashizawa, arranged from the northwest to the southeast, and the first one is the largest. These main deposits are formed in limestone along the contact with Akatani rhyolite or with other members of the Paleozoic formation. They are usually contained in skarns consisting of clinopyroxene, grandite garnet, wollastonite, ilvaite and epidote. These minerals, however, are almost completely altered to hydrous minerals such as tremolite, chlorite, talc, kaolinite and montmorillonite in the vicinity of high-grade ore bodies. Besides this alteration, extensive dolomitization of limestone is also recognized in the proximity of the deposits, and could be cited as one of the characteristic features of the deposits.

The ore of the mine consists of hematite, and minor pyrite, chalcopyrite, sphalerite and galena. Parts of hematite are often changed to magnetite, preserving its tabular crystal form. The studied specimens are collected widely from the main deposits. Although no detailed information is available on the occurrence, some old specimens at the University Museum, University of Tokyo, are also taken for analyses, because they are thought to have been collected from the upper parts of the deposits at earlier stages of the mine operation. One pyrite (No. 20 in Table 1) is taken from an intensely altered andesite, which contains large pyrite cubes of up to $2 \mathrm{~cm}$, collected at an outcrop located between the Akatani and lide mines.

The Iide $\mathrm{Zn}-\mathrm{Pb}-\mathrm{Cu}-\mathrm{Fe}$ mine The mine is located about $2 \mathrm{~km}$ east of the Akatani mine. Although the mine was closed about 15 years

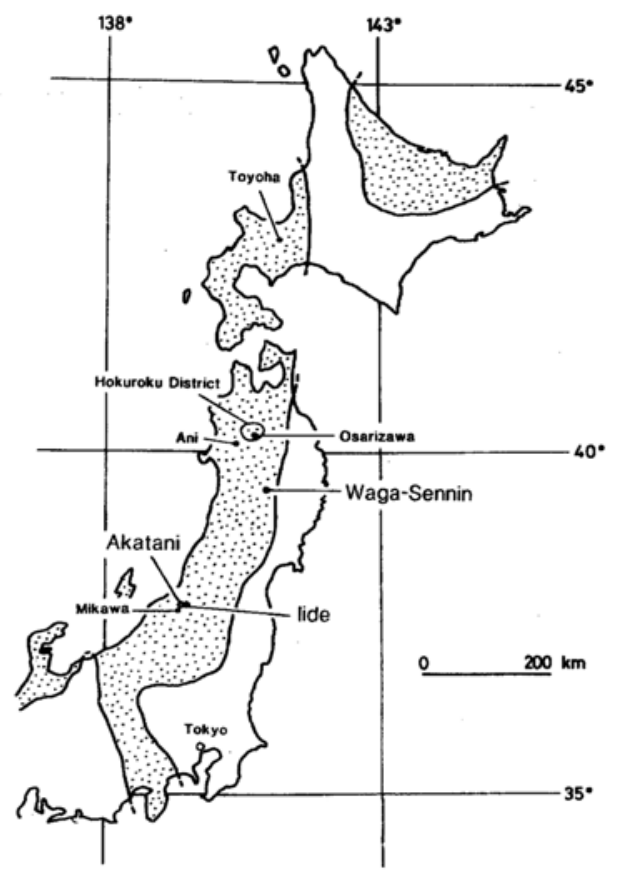

Fig. 1. Locality map of the studied deposits. Dotted parts show the "Green Tuff" region. Localities discussed in the paper are also shown except for the Iwami mine, which is located out of the map. 
Table 1. Sulfur isotopic composition of sulfide minerals from the Akatani, Iide and Waga-Sennin mines

\begin{tabular}{|c|c|c|c|c|c|c|}
\hline No. & Sample No. & Locality & Rock & Mineral & $\delta^{34} \mathrm{~S}(\% 0)$ & Assoc. ore mins. \\
\hline \multicolumn{7}{|c|}{ Akatani mine, Niigata Prefecture, $+2.8-+8.9(20)$} \\
\hline 1 & HS72070303 & Bawarizawa $480 \mathrm{~mL}$ & $\mathrm{Fe}-\mathrm{Cu}$ ore & cp & +8.8 & hm, py \\
\hline 2 & HS72070306 & ditto & Altered skarn & $\mathrm{cp}$ & 4.5 & $\mathrm{hm}(\mathrm{mt}), \mathrm{py}$ \\
\hline 3 & TY420805 & Bawarizawa No. 16 O.B. & Powdery Fe ore & py & 6.5 & hm \\
\hline 4 & HS72070403 & Mizunashizawa $280 \mathrm{~mL}$ & Clinopyroxene skarn & py & 6.3 & cp \\
\hline 5 & & & & sp & 6.5 & \\
\hline 6 & & & & gn & 5.5 & \\
\hline 7 & HS72070404 & ditto & ditto & sp & 6.5 & gn, py, hm(mt) \\
\hline 8 & HS72070409 & ditto & $\mathrm{Fe}-\mathrm{Cu}$ ore & py & 6.9 & $\mathrm{hm}$ \\
\hline 9 & & & & cp & 5.4 & \\
\hline 10 & HS72070414 & Mizunashizawa $310 \mathrm{~mL}$ & Altered skarn & py & 2.8 & sp, cp, gn \\
\hline 11 & TY422706 & Sudachizawa $368 \mathrm{~mL}$ & Brecciated rhyolite & py & 6.1 & $\mathrm{hm}$ \\
\hline 12 & UMUTPM01794 & Sudachizawa & $\mathrm{Fe}$ ore & py & 7.1 & $\mathrm{hm}, \mathrm{cp}, \mathrm{sp}$ \\
\hline 13 & UTUMPM40746 & No. 6 O.B. & Brecciated limestone & py & 5.6 & $\mathrm{hm}, \mathrm{cp}$ \\
\hline 14 & JN1303 & Details unknown & $\mathrm{Zn}-\mathrm{Pb}$ ore & sp & 8.4 & hm, cp \\
\hline 15 & & & & gn & 4.8 & \\
\hline 16 & JN1304 & ditto & $\mathrm{Fe}$ ore & py & 7.0 & $\mathrm{hm}$ \\
\hline 17 & & & & $\mathrm{cp}$ & 8.9 & \\
\hline 18 & UMUTMN01586 & ditto & ditto & py & 6.9 & $\mathrm{hm}, \mathrm{cp}$ \\
\hline 19 & UMUTMN01711 & ditto & ditto & py & 5.8 & $\mathrm{hm}(\mathrm{mt}), \mathrm{cp}$ \\
\hline 20 & HS72070401 & Surface near the mine & Altered andesite & py & 7.1 & $\mathrm{cp}, \mathrm{sp}$ \\
\hline \multicolumn{7}{|c|}{ Iide mine, Niigata Prefecture, $+3.3-+8.8$ (16) } \\
\hline 21 & I-916 & Details unknown & $\mathrm{Zn}-\mathrm{Pb}$ ore & py & +5.9 & cp \\
\hline 22 & & & & $\mathrm{sp}$ & 5.8 & \\
\hline 23 & & & & gn & 4.4 & \\
\hline 24 & I-918 & ditto & ditto & py & 5.9 & cp \\
\hline 25 & & & & sp & 8.3 & \\
\hline 26 & & & & gn & 7.0 & \\
\hline 27 & $\mathrm{I}-922$ & ditto & ditto & sp & 7.9 & py, hm(mt), gn, cp \\
\hline 28 & I-923 & ditto & ditto & py & 5.3 & $\mathrm{hm}, \mathrm{gn}, \mathrm{cp}$ \\
\hline 29 & & & & sp & 5.0 & \\
\hline 30 & I-927A & ditto & ditto & py & 7.3 & gn, cp \\
\hline 31 & & & & sp & 8.8 & \\
\hline 32 & I-947 & ditto & ditto & py & 6.1 & $\mathrm{gn}, \mathrm{hm}(\mathrm{mt}), \mathrm{cp}$ \\
\hline 33 & & & & sp & 7.8 & \\
\hline 34 & I-956 & ditto & ditto & sp & 3.3 & $\mathrm{gn}, \mathrm{hm}, \mathrm{cp}$ \\
\hline 35 & UTMDP2149 & ditto & ditto & sp & 6.5 & $\mathrm{hm}, \mathrm{py}, \mathrm{cp}$ \\
\hline 36 & & & & gn & 5.5 & \\
\hline \multicolumn{7}{|c|}{ Waga-Sennin mine, Iwate Prefecture, $+2.8-+8.6(5)$} \\
\hline 37 & TT42081707 & Shimotohbira & $\mathrm{Cu}$ ore & $\mathrm{cp}$ & 6.8 & py \\
\hline 38 & HS74110902 & Shimotohbira 7L & Altered skarn & py & 5.8 & $\mathrm{hm}(\mathrm{mt}), \mathrm{cp}$ \\
\hline 39 & HS72100405 & Kanahada dump & Powdery Fe ore & py & 2.8 & $\mathrm{hm}$ \\
\hline 40 & UMUTMN01584 & Details unknown & Powdery py ore & py & 8.6 & cp \\
\hline 41 & UMUTMN01585 & ditto & Fe ore & py & 2.9 & $\mathrm{hm}$ \\
\hline
\end{tabular}

Abbreviations: cp chalcopyrite, gn galena, $\mathrm{hm}$ hematite, $\mathrm{hm}(\mathrm{mt})$ hematite partly replaced by magnetite, py pyrite, sp sphalerite, L level, O.B. ore body.

ago, several papers provide the outline of the deposits (Iтo and Tomita, 1951; ImAI, 1952; Japan Mining Industry Association, 1965). According to these papers, the geology of both the Akatani and lide deposits is almost identical. Two main deposits, named Honko and Sudachi, are formed in limestone along the contact with Cretaceous granodiorite or plagioclase rhyolite. Skarn minerals such as clinopyroxene, grandite garnet, ilvaite, epidote, actinolite and wollastonite are often associated with ores. As in the case of the Akatani deposits, these minerals have been subjected to intense alteration to tremolite, chlorite and talc. Dolomitization of limestone is also observed, although not so strong as in the Akatani deposits.

The kind of ore minerals precipitated in the deposits is the same as in the Akatani deposits, 
but the ratio of the amount is remarkably different. In the lide mine, sphalerite and galena are predominant, and pyrite, chalcopyrite and hematitie are subordinate in amounts. Highgrade $\mathrm{Zn}-\mathrm{Pb}$ ores are often associated with quartz and calcite, and make similar appearance to "Shiroji ore" in the Kamioka $\mathrm{Zn}-\mathrm{Pb}$ skarn deposits. Hematite is often replaced partly by magnetite. The past production record of magnetite ore from the mine, shows local concentration of magnetite in the deposits. A small amount of copper was once produced from a chlorite- and pyrite-rich massive to vein-form deposit, named Komata adjacent to the west of the main deposits. No samples from this deposit were available in the present study. All but one specimen taken for the sulfur isotope analysis were collected by N. IMAI at various localities of the main deposits.

\section{The Waga-Sennin $\mathrm{Fe}$-Cu mine The mine is} located about $50 \mathrm{~km}$ south-southwest of Morioka City, Iwate Prefecture. The mine was closed in 1976. Since a classical work by ICHIMURA (1919), several papers have been published on the deposits of the mine (e.g. ImaI, 1960, 1977; UENo, 1975; ImaI et al., 1976). According to these papers, similarity of geological and mineralogical features is apparent between the deposits of this area and of the Akatani-lide region. The basement rocks consist of metamorphic rocks and late Cretaceous granodiorite to leucogranite intruding the former. The metamorphic complex is composed of biotite schist, biotite gneiss, biotite hornfels and crystalline limestone. Original rocks are thought to be of Permian. Covering and intruding the basement rocks, Neogene sedimentary and igenous rocks are widely distributed. Among them, it is noteworthy that plagioclase rhyolite of middle Miocene occurs as dike swarms and stocks in the mining area.

There are several main deposits in the mine. They are formed in limestone with altered skarns along the contact with Cretaceous granitic rocks. Skarn minerals include clinopyroxene, grandite garnet and epidote. As in the Akatani and Iide deposits, they are intensely altered to tremolite, chlorite, talc and montmorillonite in the vicinity of ore bodies. Dolomitization of limestone also occurs extensively. Igneous and metamorphic rocks near the deposits are partly subjected to silicification, sericitization and chloritization. A main ore mineral is hematite, being partly or thoroughly replaced by magnetite. Minor pyrite and chalcopyrite are associated, and the latter shows local concentration along fissures and faults. Rare occurrences of sphalerite, galena and even pyrrhotite are reported. Unfortunately only a small number of specimens were available for the present study. Some of them were collected from the main deposits, named Shimotohbira and Kanahada.

Genesis of the ore deposits Owing to close spatial relations of ore deposits to Cretaceous granitic rocks, these deposits under consideration were once believed to have been formed with genetical relations to the granitic rocks (e.g. ICHIMURA, 1919). Later detailed studies, however, afforded abundant geological evidence of ore depositions genetically connected with the volcanic activity of plagioclase rhyolites of middle Miocene. For example, large ore bodies in the Bawarizawa deposit, the Akatani mine, are formed along the basal plane of a plagioclase rhyolite lava flow and along a volcanic vent of this magma (MoRITA, 1960; SUZUKI, 1970). In the Waga-Sennin mine, IMAI (1977) found that parts of plagioclase rhyolite dikes are subjected to hydrothermal alteration and chalcopyritehematite dissemination. Based on remanent magnetic data of ores and igneous rocks, UENO (1975) concluded that the Waga-Sennin hematite deposits were genetically related to the plagioclase rhyolite. In all areas, plagioclase rhyolites adjacent to the deposits were more or less subjected to hydrothermal alterations. These lines of evidence undoubtedly indicate the middle Miocene formation of the studied deposits in considerably shallow environments.

According to NaGaSAWA (1951), the Mikawa $\mathrm{Au}-\mathrm{Ag}-\mathrm{Cu}-\mathrm{Zn}-\mathrm{Pb}$ vein deposits are situated about $5 \mathrm{~km}$ southwest of the Akatani mine, and are 
formed with the genetical relation to the activity of Akatani rhyolite. Ores consist of chalcopyrite, sphalerite, galena, pyrite, hematite, argentite and native gold, with quartz, chlorite, dolomite to ankerite, sideirte, kaolinite, adularia and barite as gangue minerals. Sericitization, silicification and chloritization of wall rocks are remarkable. The occurrence of, and mineral assemblages in, the deposits, strongly suggest that the ore-forming solution responsible for the deposits is almost identical with those for the Akatani and lide deposits. That is, the Mikawa deposits seem to be a vein-form equivalent to the studied deposits. Similar vein deposits are widely distributed in the "Green Tuff" region. Two of the representatives of such Au-Ag-Cu$\mathrm{Zn}-\mathrm{Pb}$ veins are the Osarizawa and Ani deposits, Akita Prefecture. As stated previously, sulfur isotope data are available on these deposits (TATsumi, 1965). As to minerals in the Fe-O-S system, hematite-pyrite assemblage is common, and sericitization, silicification and chloritization of wall rocks are also extensive in these deposits (Japan Mining Industry Association, 1968). These features might allow us to suppose that these vein deposits, as well as the Mikawa deposits, were formed under conditions similar to those for the studied deposits, as discussed in later sections.

\section{EXPERIMENTAL}

Sulfide minerals were separated from hand specimens by hand picking. Purity of the minerals is more than $95 \mathrm{vol}$. percent in most cases. Some sphalerites from the lide mine have many small dots of chalcopyrite, and the amount of impurity reaches 10 vol. percent in some cases. All sulfide minerals were finally converted to $\mathrm{Ag}_{2} \mathrm{~S}$ by the procedure described by ThODE et al. (1961). $\quad \mathrm{Ag}_{2} \mathrm{~S}$ obtained was combusted to $\mathrm{SO}_{2}$ at $1,200^{\circ} \mathrm{C}$ in a stream of tank air for the mass spectrometry. The mass spectrometer used for the isotope analysis has been described by SAKAI et al. (1970). The results of the isotope analysis are given in the $\delta^{34} \mathrm{~S}$ value as defined by:

$$
\begin{gathered}
\delta^{34} \mathrm{~S}(\% 0)=\left[\left({ }^{34} \mathrm{~S} /{ }^{32} \mathrm{~S}\right)_{\text {sample }} /\left({ }^{34} \mathrm{~S} /{ }^{32} \mathrm{~S}\right)_{\text {standard }}\right. \\
-1] \times 1,000
\end{gathered}
$$

The standard is troilite sulfur from the Canyon Diablo meteorite. The uncertainty in $\delta^{34} \mathrm{~S}$ values is less than $\pm 0.2 \%$ in most cases.

\section{RESUlts AND Discussion}

$\delta^{34} S$ values of sulfide minerals Sulfur isotope data obtained are summarized in Table 1, and graphically shown in Fig. 2. All values are distributed in a range from about +3 to $+9 \%$, irrespective of deposits. In each mine, any systematic change of the values is not observed for different occurrences, such as levels, ore bodies, mineral assemblages and so on. The range, +3 to $+9 \%$, is rather broad, compared with other skarn deposits in Japan. That is, the narrow isotopic composition range of sulfide sulfur has been emphasized by previous workers as one of the characteristic features of the skarn deposits. The contrast is graphically demonstrated in Fig. 3. As discussed later, however, positive and relatively wide-range values coincide with those for the vein and kuroko deposits in the "Green Tuff" region. In this respect, it is clear that the studied deposits have a characteristic common to the deposits formed in the "Green Tuff" region.

From some samples, two or three minerals apparently coexisting grain by grain were sepa-

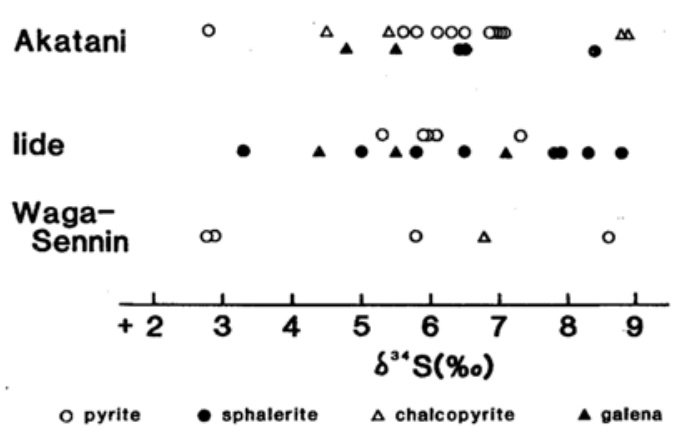

Fig. 2. Distribution of $\delta^{34} S$ values of sulfide minerals from the studied deposits. 
rated for the analysis. These pairs are shown in Table 1 with the same sample numbers. Temperatures estimated for these coexisting sulfide minerals using experimental temperature scales given by KAJWARA and KROUSE (1971), vary from $200^{\circ} \mathrm{C}$ to unreasonably high values. In addition, some pairs exhibit isotopic fractionation reverse to the equilibrium trend expected from the experiments. The same relationship was experienced in the course of the previous study on some Japanese skarn deposits (SHIMAZAKI and Yамамото, 1979). In the present study, the reverse fractionation is observed especially on the pairs with pyrite. There is, however, no evidence for the precipitation of pyrite at a stage different from that of $\mathrm{Cu}-\mathrm{Zn}$ $\mathrm{Pb}$ mineralizations. Pyrite and chalcopyrite are known as the minerals difficult to attain isotopic equilibrium with other sulfide mienrals under certain conditions (Онмото and RYE, 1979). It is reasonable, therefore, to suppose that only incomplete isotopic equilibrium was attained among sulfide minerals at the time of precipitation of the studied deposits.

Physicochemical conditions of ore deposition As summarized in previous pages, the mineral assemblages observed in the studied deposits are identical with each other. This fact would allow us to assume a common ore-forming solution responsible for all the deposits under consideration. The sulfur isotope data obtained seem to support this assumption. Although the ratio of the amounts of metals precipitated is quite different in these deposits, there seems no evidence of remarkable differences with respect to major characteristics of the solutions.

ENJoI (1972) reported the data on fluid inclusions found in quartz from the Akatani mine; filling temperature of 250 to $315^{\circ} \mathrm{C}$, and salinity of 1.6 to $4.5 \mathrm{wt} \% \mathrm{NaCl}$ equivalent. Intense alterations of skarn minerals to clayey material also strongly suggest considerably low temperatures for the precipitation of sulfide and oxide minerals in the deposits. On the basis of these lines of evidences, temperature of the

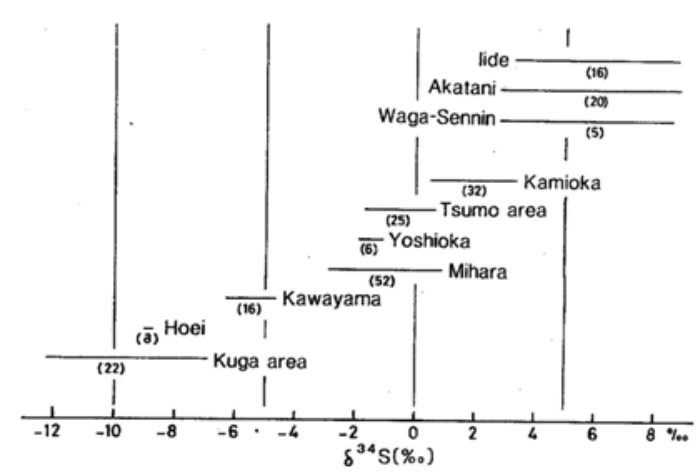

Fig. 3. Distribution of $\delta^{34} S$ values of sulfide minerals from the skarn deposits in Japan. Numbers in parentheses represent the number of samples analyzed. References are: first three (this study), Kamioka (KIYOSU and NAKAI, 1971), Mihara (YAMAMOTO, 1976), and other deposits (SHIMAZAKI and YAMAMOTO, 1979).

solution will be assumed as $250^{\circ} \mathrm{C}$, and ionic strength as unity. These assumptions allow us to draw the stability fields of hematite, magnetite and pyrite as shown in Fig. 4 after Онмото (1972). The mineral assemblages observed in the three studied mines, undoubtedly indicate that the ore precipitation occurred under the conditions represented in the figure by the area close to the point where these three minerals can coexist.

As to $\mathrm{pH}$ of the solution, extensive occurrence of kaolinite in the Akatani deposits and sericitization of wall rocks in the Waga-Sennin deposits, might suggest the value close to the stability boundary between kaolinite and sericite. Montoya and Hemley (1975) give:

$$
\log \left(\left[\mathrm{K}^{+}\right] /\left[\mathrm{H}^{+}\right]\right)=2.8
$$

along the stability boundary at $250^{\circ} \mathrm{C}$. Here brackets mean thermochemical activities. If $\left[\mathrm{K}^{+}\right]$in the solution could be assumed to be less than $0.1, \mathrm{pH}$ value should be higher than 3.8 . This assumption could be acceptable considering that the ionic strength of the solution is close to unity. Carbonate minerals are stable in the deposits. The dissociation of calcite gives strict constraint to $\mathrm{pH}$ of the solution. Helgeson's (1969) compilation gives: 


\section{$\log \left(\left[\mathrm{Ca}^{++}\right]\left[\mathrm{H}_{2} \mathrm{O}\right] \mathrm{PcO}_{2} /\left[\mathrm{CaCO}_{3}\right]\left[\mathrm{H}^{+}\right]^{2}\right)$$$
=8.8
$$

at $250^{\circ} \mathrm{C}$. That means, if $\mathrm{pH}$ value of the solution becomes lower than about $4,\left[\mathrm{Ca}^{++}\right]$and/or $\mathrm{P}_{\mathrm{CO}_{2}}$ would reach unreasonably high values. These considerations lead to the conclusion that $\mathrm{pH}$ value of the solution was not much lower than 4. The conclusion also means that the total sulfur content of the solution is nearly $0.1 \mathrm{moles} / \mathrm{kg} \mathrm{H}_{2} \mathrm{O}$ as shown in Fig. 4. The hatched area in the figure represents the estimated condition for the ore depositions.

Sulfur isotopic value of the ore-forming solution In Fig. 4, calculated $\delta^{34} \mathrm{~S}$ values of pyrites are also shown after Онмото (1972), on the assumption of complete isotopic equilibrium between pyrites and the solution in which $\delta^{34} \mathrm{~S}$ value of total sulfur is zero per mil. The figure shows that the $\delta^{34} \mathrm{~S}$ value of total sulfur in the solution is about $26 \%$ o heavier than that of pyrite under the supposed condition. According to this figure, the averaged $\delta^{34} \mathrm{~S}$

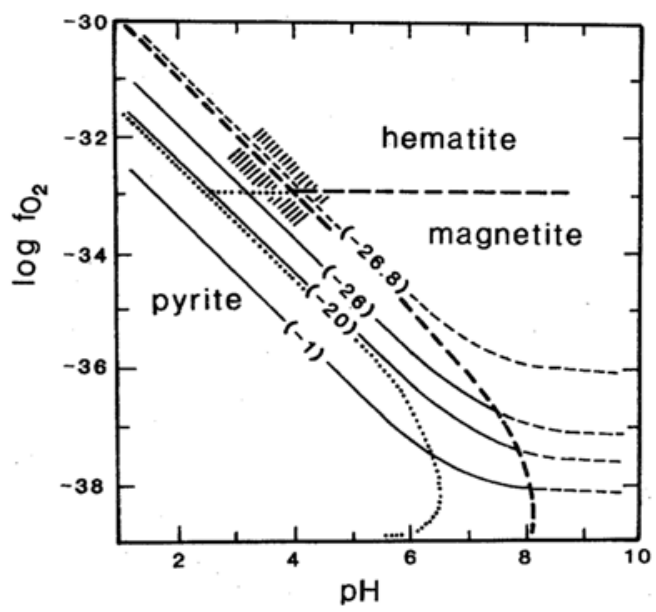

Fig. 4. The stability fields of Fe-O-S minerals shown by thick broken and dotted lines at total sulfur contents of 0.1 and 0.01 moles $/ \mathrm{kg} \mathrm{H}_{2} \mathrm{O}$, respectively (after ОНМото, 1972). The hatched area indicates the estimated condition for the formation of the studied deposits. $\delta^{34} S$ contours for pyrite precipitated under complete isotopic equilibrium is also shown from the solution of zero per mil $\delta^{34} S$ for total sulfur, $T=250^{\circ} \mathrm{C}$ and $I=1.0$. value, say $+6 \%$, of pyrites obtained in this study, means that the $\delta^{34} \mathrm{~S}$ value of total sulfur in the solution is as heavy as $+32 \%$, if isotopic equilibrium was attained during the ore precipitation.

As stated in previous pages, however, only incomplete isotopic equilibrium is observed among sulfide minerals in the studied deposits. This fact strongly suggests that the above estimation on the $\delta^{34} \mathrm{~S}$ value of total sulfur on the assumption of complete isotopic equilibrium, is not applicable in the present study. In recent works (e.g., Онмото and LASAGa, 1982; Shelton and RYE, 1982), it is confirmed that isotopic equilibrium between aqueous $\mathrm{H}_{2} \mathrm{~S}$ and sulfide minerals is attained faster than isotopic equilibrium between aqueous sulfate and aqueous sulfide. In the studied deposits, even the aqueous $\mathrm{H}_{2} \mathrm{~S}$ - sulfide minerals isotopic equilibria were not attained. Therefore, isotopic equilibria among sulfur species in the solution could not be expected to have attained. This means that the rate of sulfide precipitation is much greater than the rate of the isotopic exchange reaction between aqueous sulfide and sulfate ions. The difficulty of obtaining this exchange equilibrium in natural ore-forming processes is pointed out in some previous works (e.g. SAKAI, 1968).

According to Онмото and LASAGA (1982), almost half a year would be required for the attainment of isotopic exchange equilibrium under the condition of $\mathrm{T}=250^{\circ} \mathrm{C}, \mathrm{pH}=4$ and total sulfur of $0.1 \mathrm{~mole} / \mathrm{kg} \mathrm{H}_{2} \mathrm{O}$. In the solution under consideration, as estimated above, sulfate sulfur predominated over sulfide sulfur. Slight reduction of sulfate ions, the solution being still in the $\mathrm{f}_{\mathrm{O}_{2}}$ field above hematite-magnetite stability boundary, or increase in the activity of simple cations of metals due to the breakdown of complex ions, or both occurred at the sites of ore deposition, and resulted in faster precipitation of sulfide minerals compared with the isotopic exchange reaction. These considerations lead to the conclusion that the important factor controlling the isotopic composition of sulfide minerals is rather the kinetic effect of sulfate reduction than the exchange 
reaction between sulfate and sulfide species in the solution.

Only little is known about the kinetic isotopic effect of non-biogenic reduction of sulfate ions (Онмото and RYE, 1979). Kryosu (1980) reported the effect of 7 to $9 \%$ in the reduction of $\mathrm{H}_{2} \mathrm{SO}_{4}$ and $\mathrm{NaHSO}_{4}$ solutions by dextrose at $\mathrm{pH}=1$ and temperatures from 250 to $340^{\circ} \mathrm{C}$. As shown in his experiments, however, the reduction rate depends on $\mathrm{pH}$ and sulfate species as well as temperature. In fact, only slight reduction and no isotopic fractionation was observed in his experiments in the case of $\mathrm{Na}_{2} \mathrm{SO}_{4}$ solution. In some natural hydrothermal systems, very small fractionations, say less than two per mil, between sulfate and sulfide species are reported from Broadland and Ngawha (Онмото and LASAGA, 1982, Fig. 7). The rate of nonbacterial reduction of sulfates depends also on the types of reducing compounds as pointed out by Онмото and LASAGA (1982). The kinetic isotopic effect increases with a decrease in the rate of reduction (Онмото and RYE, 1979). In the natural process under consideration, it is difficult to estimate all such factors controlling the kinetic effect, especially the reducing compounds which have caused the sulfide precipitation.

On the basis of above consideration, it only could be stated that the kinetic fractionation of nearly zero to ten per mil might have occurred during the sulfate reduction in the studied deposits. It seems, however, most reasonable to the present writers to conclude tentatively that the kinetic effects of the sulfate reduction were not so large that the sulfur isotopic values of sulfates in the ore-forming solution was reserved approximately as the values of sulfide minerals in these deposits. The reason of this tentative conclusion will be stated in the following section.

COMPARISON WITH OTHER DEPOSITS IN THE

"Green TuFF" Region AND Possible SOURCE OF ORE SULFUR

It is worthy to note that the obtained iso-

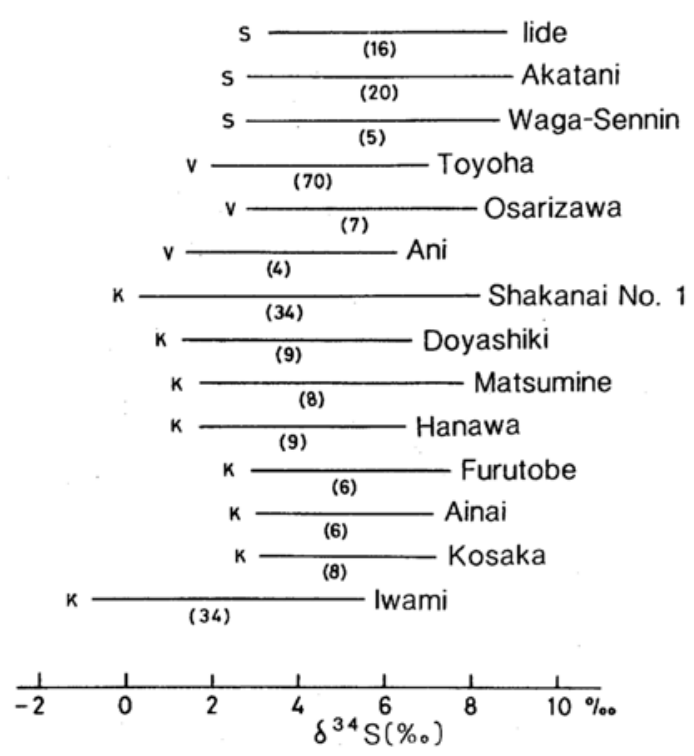

Fig. 5. Distribution of $\delta^{34} S$ values of sulfide minerals from the deposits in the "Green Tuff" region. Abbreviations are: $s$ skarn, $v$ vein and $k$ kuroko deposits. Numbers in parentheses represent the number of samples analyzed. References are: first three deposits (this study), Toyoha (KIYOSU, 1974), Osarizawa and Ani (TATSUMI, 1965), Shakanai No. 1 †KAJIWARA, 1971), Doyashiki to Kosaka (KAJIWARA and DATE, 1971) and Iwami (YAMAMOTo, 1974b). All kuroko deposits except for Iwami are located in the Hokuroku district shown in Fig. 1.

topic values coincide with those for the ores from vein and kuroko deposits in the "Green Tuff" region. The sulfur isotope data available to date for the ores from the region are summarized in Fig. 5. Studied minerals in these works are the same as those in the present study, namely pyrite, chalcopyrite, sphalerite and galena, except for TATSUMI's (1965) work, which includes tetrahedrite and bornite, too. Based on these data, it could be stated with certain confidence that the $\delta^{34} \mathrm{~S}$ values of sulfide minerals fall mostly in the range of +2 to $+9 \%$ for Miocene ore deposits formed in the "Green Tuff" region.

As stated previously, some major vein deposits in the "Green Tuff" region, such as the Osarizawa and Ani deposits, are thought to have been formed under conditions similar to those 
for the studied deposits, that is, high oxygen fugacity indicated by the precipitation of hematite, relatively low $\mathrm{pH}$ indicated by sericite, and relatively low formation temperatures around $250^{\circ} \mathrm{C}$ estimated from fluid inclusion data, as summarized in Japan Mining Industry Association (1968). According to TATSUMI (1965), sulfur isotope values are +2.8 to $+8.1 \%$ and +1.4 to $+6.3 \%$ for the Osarizawa and Ani deposits, respectively, as shown in Fig. 5. On the Toyoha vein deposits, KIYosu (1974) reported +2.0 to $+7.0 \%$ of $\delta^{34} \mathrm{~S}$ values for sulfide minerals as shown in Fig. 5, and stated that sulfide minerals were precipitated from aqueous sulfide species partly disequilibrated with the redox environments. Because the mineral assemblages in the Fe-O-S system observed in the deposits clearly show variable oxygen fugacity prevailed during the mineralization (e.g. ShiKazono, 1975). As to the Shakanai No. 1 kuroko deposits, KaJiwara (1971, Fig. 8) explained the $\delta^{34} \mathrm{~S}$ value of sulfide minerals, +0.3 to $+8.2 \%$, supposing that sulfides precipitated from Miocene sea water sulfate of $+20 \%$, under conditions near the stability boundary of sulfide and sulfate species in the solution. If this is the case, considerably constant oxygen fugacity had to be achieved throughout the time of ore formations in many different kuroko deposits.

Recently SASAKI and IsHIHARA (1980) established a positive correlation between isotope ratios of sulfur from granitoids and from related hydrothermal deposits. IsHIHARA and SASAKI (1978) extended this idea to the deposits in the "Green Tuff" region including kuroko, and tried to explain the isotopic regularity supposing granitic magma as the source of sulfur. If this is the case, no large isotopic fractionation could have occurred during complex transportation and precipitation processes, although they made no comments on it. Especially in the case of the deposits associated with the magnetite-bearing felsic igneous rocks, such as those in the "Green Tuff" region, little isotopic exchange and kinetic effects should be supposed, because the large amounts of sulfur is thought to be derived from the magmas in the form of sulfates (BURNHAM and Онмото, 1980).

In short, there have been various models proposed on the $\delta^{34} \mathrm{~S}$ values for the deposits in the "Green Tuff" region. If the sulfide ores in the "Green Tuff" region were really formed through the processes proposed by various authors, the common range of $\delta^{34} \mathrm{~S}$ values among skarn, vein and kuroko deposits, say +2 to $+9 \%$ o as found in Fig. 5, is concluded to be nothing more than coincidence. To the present writers, however, the range given above does not seem to be a result of coincidence. Because, it is possible to give simpler and more plausible explanation for the obtained common range, supposing extensive and homogeneous reservoirs of sulfur with several per mil positive $\delta^{34} \mathrm{~S}$ values, and also supposing little kinetic effects of sulfate reduction at the sites of sulfide precipitation as stated in the previous section. Otherwise the isotopic values for sulfide minerals would be very variable, owing to different oxidation states of the ore-forming fluids prevailed in the "Green Tuff" region. As extensive sulfur reservoirs, Miocene felsic igneous rocks seem to be the most plausible, as suggested by IsHIHARA and SASAKI (1978).

The rather broad isotopic range for the deposits in the "Green Tuff" region might be due to the small kinetic effects of sulfate reduction. On the contrary, the narrow isotopic range for skarn deposits shown in Fig. 3, could be explained by the precipitation of minerals from sulfide sulfur-rich solutions. Most of the deposits given in Fig. 3 except those studied in the present paper, are thought to have been formed under relatively reducing conditions. It is apparent that necessary are the accumulation of more isotopic data on individual deposits with estimation of oxidation state of the ore-forming solutions, and further examinations of the data from the viewpoint of exchange and kinetic fractionations among sulfur species in the oreforming solutions.

Acknowledgements-The authors are deeply indebted to Professor H. SAKAI of the Institute for Thermal Spring Research, Okayama University, for his helpful advice and support in the mass spectrometry. Thanks are also 
due to Professor N. ImaI of Waseda University for providing specimens from the Iide mine. This article was made possible through his generous help. Fruitful discussions with Dr. N. SHIKAZONO of University of Tokyo, Dr. Y. KAJIWARA of Tsukuba University and Dr. A. SASAKI of Geological Survey of Japan, are gratefully acknowledged. A part of the study was supported with a grant-in-aid offered to one of the authors (HS) by the ITO Science Foundation.

\section{REFERENCES}

BURNHAM, C. W. and OHMOTO, H. (1980) Late-stage processes of felsic magmatism. Mining Geol. Spec. Issue 8, 1-11.

ENJOJI, M. (1972) Studies on fluid inclusions as the media of the ore formation. Sci. Rep. Tokyo Univ. Educ., Sec. C 11, 79-126.

HELGESON, H. C. (1969) Thermodynamics of hydrothermal systems at elevated temperatures and pressures. Am. J. Sci. 267, 729-804.

ICHIMURA, T. (1919) Geology and ore deposits of the Sennin mine. J. Geol. Soc. Japan 26, 428-443, 469-496, 519-551 (in Japanese).

IMAI, N. (1952) Studies on the Akatani iron deposit and the Iide lead-zinc deposit in Niigata Prefecture, Japan. With special reference to the mineralization, related igneous activities and metallogeny. J. Fac. Sci., Niigata Univ., Ser. II 1, 1-112 (in Japanese).

IMAI, N. (1960) Genesis of the hematite deposits in the Inner Zone of northeastern Japan, with special reference to those of the Akatani and Sen-nin iron mines. J. Fac. Sci., Niigata Univ., Ser. II 3, 205256.

IMAI, N. (1977) Genesis of the iron-copper deposits of the Waga-Sennin mine, Iwate Prefecture. in Study on contact metasomatic deposits. Memorial issue for the retirement of Prof. T. MIYAZAWA B1-B12 (in Japanese).

ImAI, N., OTSUKA, R., HoNDA, S., ISODA, N. and SUZUKI, S. (1976) Serpentines associated with hydrothermal dolomite-rock at the Waka Sen-nin mine, Iwate Prefecture, Japan. J. Japan. Assoc. Min. Petr. Econ. Geol. 71, 339-359.

IMAI, N. and YAMAZAKI, S. (1967) Hydrothermal dolomite-rocks associated with hematite deposits of the Akatani mine, Niigata Prefecture, northeastern Japan. Mem. School Sci. Eng., Waseda Univ. 31, 1163.

ISHIHARA, S. and SASAKI, A. (1978) Sulfur of kuroko deposits - A deep seated origin? Mining Geol. 28, 361-367.

ISHIHARA, S., SATO, K. and TsukimuRA, K. (1981) Some aspects on the tin-polymetallic veins in the Akenobe mine area, Southwest Japan. Mining Geol.
31, 147-156 (in Japanese).

ITO, S. and TOMITA, M. (1951) Report of lead and

zinc deposit of the lide mine in Niigata Prefecture, with special reference to the structural control of the ore deposit. Bull. Geol. Surv. Japan 2, 158-160 (in Japanese).

Japan Mining Industry Association (1965) Ore deposits in Japan (1). Japan Mining Industry Assoc., Tokyo 581p (in Japanese).

Japan Mining Industry Association (1968) Ore deposits in Japan (2). Japan Mining Industry Assoc., Tokyo 941p (in Japanese).

KAJIWARA, Y. (1971) Sulfur isotope study of the Kuroko-ores of the Shakanai No. 1 deposits, Akita Prefecture, Japan. Geochem. J. 4, 157-181.

KaJIWARA, Y. and DATE, J. (1971) Sulfur isotope study of Kuroko-type and Kieslager-type stratabound massive sulfide deposits in Japan. Geochem. J. 5, 133-150.

KaJiWARA, Y. and Krouse, H. R. (1971) Sulfur isotope partitioning in metallic sulfide systems. Canadian J. Earth Sci. 8, 1397-1408.

KIYOSU, Y. (1974) Sulfur isotopic compositions of epithermal vein type sulfides from the Toyoha mine, Hokkaido, Japan. J. Earth Sci., Nagoya Univ. 22, 23-32.

KIYOSU, Y. (1977) Sulfur isotope ratios of ores and chemical environment of ore deposition in the Taishu $\mathrm{Pb}-\mathrm{Zn}$ sulfide deposits, Japan. Geochem. J. 11, 9199.

KIYOSU, Y. (1980) Chemical reduction and sulfurisotope effects of sulfate by organic matter under hydrothermal conditions. Chem. Geol. 30, 47-56.

KIYOSU, Y. and NAKAI, N. (1971) Sulfur isotope ratios of ores from the Kamioka mine. Abstr. Joint Meeting of Five Earth Sci. Societies 176 (in Japanese).

MONTOYA, J. W. and HeMleY, J. J. (1975) Activity relations and stabilities in alkali feldspar and mica alteration reactions. Econ. Geol. 70, 577-594.

MORITA, H. (1960) Geology and ore deposits of the Akatani mine, with special reference to the structural features controlling the localization of the Bawarizawa "main" deposit. Mining Geol. 10, 338-345 (in Japanese).

NAGASAWA, K. (1951) Geology and ore deposits of the Mikawa mine, Niigata Prefecture. J. Geol. Soc. Japan 57, 357-365 (in Japanese).

Онмото, H. (1972) Systematics of sulfur and carbon isotopes in hydrothermal ore deposits. Econ. Geol. 67, 551-578.

Онмото, H. and LASAGA, A. C. (1982) Kinetics of reactions between aqueous sulfates and sulfides in hydrothermal systems. Geochim. Cosmochim. Acta 
46, 1727-1745.

Онмото, H. and RYE, R. O. (1979) Isotopes of sulfur and carbon. in H. L. BARNES (ed.) Geochemistry of hydrothermal ore deposits, 2nd ed., John Wiley and Sons, New York, 509-567.

SAKAI, H. (1968) Isotopic properties of sulfur compounds in hydrothermal processes. Geochem. J. 2, $29-49$.

SAKaI, H., MATSUbaYa, O. and NaKaJima, Y. (1970) On the new McKinney type mass spectrometer recently installed in the Institute for Thermal Spring Research, Okayama University. Mass Spectroscopy 18, 1195-1204.

SASAKI, A. and ISHIHARA, S. (1980) Sulfur isotope characteristics of granitoids and related mineral deposits in Japan. Proc. 5th LAGOD Symp. 1, 325335.

SHELTON, K. L. and RYE, D. M. (1982) Sulfur isotopic compositions of ores from Mines Gaspe, Quebec: An example of sulfate-sulfide isotopic disequilibria in ore-forming fluids with applications to other porphyry-type deposits. Econ. Geol. 77, 1688-1709.

SHIKAZONO, N. (1975) Mineralization and chemical environment of the Toyoha lead-zinc vein-type deposits, Hokkaido, Japan. Econ. Geol. 70, 694-
705.

ShimaZaKi, H. and Yamamoto, M. (1979) Sulfur isotope ratios of some Japanese skarn deposits. Geochem. J. 13, 261-268.

SUZUKI, Y.(1970) Geology and copper mineralization of the Akatani mine, Niigata Prefecture, Japan. Mining Geol. 20, 276-294 (in Japanese).

TATSUMI, T. (1965) Sulfur isotopic fractionation between coexisting sulfide minerals from some Japanese ore deposits. Econ. Geol. 60, 1645-1659.

THODE, H. G., MONSTER, J. and DUNFORD, H. B. (1961) Sulfur isotope geochemistry. Geochim. Cosmochim. Acta 25, 565-578.

UENO, H. (1975) Paleomagnetism and origin of the Sen-nin hematite deposits in northeastern Japan. Econ. Geol. 70, 547-553.

YAмамото, M. (1974a) Distribution of sulfur isotopes in the Ryusei vein of the Akenobe mine, Hyogo Prefecture, Japan. Geochem. J. 8, 75-86.

YAMAмото, M. (1974b) Distribution of sulfur isotopes in the Iwami Kuroko deposits, Shimane Prefecture, Japan. Geochem. J. 8, 27-35.

YAmamoto, M. (1976) Relationship between Se/S and sulfur isotope ratios of hydrothermal sulfide minerals. Min. Deposita 11, 197-209. 